\title{
Development of the yeast Saccharomyces cerevisiae as a biosensor for
}

\author{
the toxicity detection of toxic substances
}

\section{Linlin Gong, Guang Yang* , Bo Yang, Jihui Gu}

Department of Medical Devices and Food, University of Shanghai for Science and

Technology, Shanghai 200093, China

Abstract: A whole-cell biosensor developed with yeast Saccharomyces cerevisia to detect the toxicity of chlorothalonil has been developed. This biosensor relied on the inhibition effect for metabolism by toxicants to provide detection and the degree of toxicity to yeast cells. In order to further improve the toxic sensitivity of yeast cells biosensor, the effect of the action time, the initial $\mathrm{pH}$ value of the medium and the temperature on inhibiting cell growth were investigated. Response surface regression analysis was conducted to obtain optimal culture conditions. Th effects of treated yeast morphology, ROS, DNA, caspase 3 activity were analyzed. This optimized yeast as a biosensor was used to detect chlorothalonil and heavy metals. The results are as follows: at optimal culture conditions, $\mathrm{EC}_{50}$ values of chlorothalonil to yeast biosensor determined at incubation time $4 \mathrm{~h}$ increased from $0.25 \mu \mathrm{g} \cdot \mathrm{mL}^{-1}$ in the control to $0.006 \mu \mathrm{g} \cdot \mathrm{mL}^{-1}$, which increased by 41.67 times. Compared with the control yeast cells, the morphology of optimized yeast cells were more transparent, with significantly increased intracellular vesicle rate and cell membrane permeability, intracelluar ROS increased siginificantly, DNA bands extracted was ladder, and caspase 3 activity was stimulated. The yeast biosensor had a high sensitivity to heavy metals. After analysis, many treated cells were apoptosis which was the main reason for the increasing sensitivity to detect harmful substances. It was found that the method provides a new idea for the detection of harmful substances in the environment.

Key words: yeast; culture conditions; chlorothalonil; sensitivity; biosensor; heavy metal

Yeast cells biosensor could be used to detect harmful substances in the environment, sunch as chlorothalonil, heavy metals. Even through chemical analysis methods, such as ICP-MS and High Performance Liquid Choromatography (HPLC), have strengths in accuracy and limit of detection, it is impossible to evaluate the cytotoxicity and the biological effect of waste water by chemical result alone, and it is also expensive, prolix and complicated. However, the yeast cell biosensor is easy to operate, is sensitive to various toxicants, comparable to the other totxicity detection methods, is cheap in cost, and has. Therefore, the method which used yeast cells as biosensor will have great potential in the detection of the cytotoxicity of waste water in the future.

\footnotetext{
* Corresponding author. Department of Medical Devices and Food, University of Shanghai for Science and Technology, Shanghai 200093, China

E-mail address:luke_yang @126.com
} 


\section{Instructions}

Chlorothalonil (2,4,5,6-tetrachloroisophthalonitrile) is one of the most commonly used non-absorbable broad-spectrum fungicides, which is widely used in fruits, vegetables, grains and other crops[1]. Due to the widespread use of chlorothalonil, it is frequently reported that chlorothalonil remains in the atmosphere, water, soil and other environmental media[2-3]. According to the relevant toxicology experiments, chlorothalonil has accumulation effect in animals. If it exceeds a certain range, it will cause many serious chronic diseases. In especially, chlorothalonil has a certain connection with cancer[4]. Thus, chlorothalonil has been included in the list of chemical carcinogens in the United States[5].

At present, the main method to detect chlorothalonil is chemical analysis, but it does not conform to the twelve principles of green chemistry. They are usually expensive, with using a large number of toxic and environmentally harmful solvents. These solvents consume a lot of resources and produce harmful and toxic wastes [6]. Therefore, it is necessary to develop a reliable technology that can meet the requirements of green analytical chemistry, and the microbial inhibition method has the advantages of green environmental protection, low cost, simple and fast operation, and multifunctional detection combining analytical concentration and toxicity.

Biosensor is one of the important biological methods to detect harmful substances in the environment. In the early stage of biosensor development, fish, mouse algae, water flea and other individuals were mainly used. Using paramecium to detect the residual pesticide oxole pesticide in sewage [7]. Bee larvae have been used to detect chlorothalonil residues in water [8], however, due to the long growth cycle of individuals, it is not conducive to rapid detection requirements. With the establishment of cell-based system to evaluate the toxicity of harmful substances, at present, it is mainly used to detect the toxicity of harmful substances by using the characteristics of microbial physiological reaction, its own luminous characteristics or cell membrane. It has been studied to use Saccharomyces cerevisiae cells to determine the fungicide nitrogen disulfide, organic phosphorus pesticide and imidacloprid in waste water [9-10]. At present, the microbiological method mostly were utilizing yeast Saccharomyces cerevisia to detect estrogen in milk [11], and uses Vibrio Fischer, E.coli, pale bacteria to detect new harmful substances and heavy metals in waste water [12-14]. Although compared with the use of individual animals for toxicity detection, the microbiological method is low-cost, short-time and fast, it also has some disadvantages, such as the luminous bacteria must work in a certain salt solution and the number of cells would affect the optical signal and the detection error. In addition, it is believed that microorganisms with similar structure to higher organisms can more effectively respond to the toxicity of harmful substances. Yeast is a single cell eukaryote with a size of 10-20 $\mu \mathrm{m}$. Because of its advantages of easy culture and rapid proliferation, yeast cell is regarded as an ideal model biomaterial in modern biological research [15], such as the acute toxicity of endocrine disruptors, sewage sediments, heavy metals and other chemicals [16-18].

The purpose of this study is to develop and optimize the yeast cell for the determination of chlorothalonil. In this experiment, yeast Saccharomyces cerevisia were utilized as a biosensor to detect the toxicity of chlorothalonil. The bioassay method has three important advantages: first, it can significantly improve the semi inhibition concentration of chlorothalonil; second, it can carry out toxicity test for different heavy metals; third, it has high accuracy and accuracy. Within a certain range of harmful substance concentration, the yeast cell $\mathrm{OD}_{600}$ is inversely proportional to 
the harmful substance concentration, and the yeast cell activity is weakened by changing the yeast cell culture conditions, so as to improve high concentration of chlorothalonil in yeast cells. Compared with the untreated yeast cells, the damaged yeast $\mathrm{OD}_{600}$ would change significantly. The results showed that the decrease of yeast $\mathrm{OD}_{600}$ under toxic and non-toxic conditions were directly proportional to the concentration of harmful substances, which provided the inhibition index. In addition, the toxicity of heavy metal $\mathrm{Cu}^{2+}, \mathrm{Cd}^{2+}, \mathrm{Pb}^{2+}, \mathrm{Hg}^{2+}, \mathrm{Cd}^{6+}$ in simulated waste water by yeast cell biosesor was introduced.

\section{Materials and methods}

\subsection{Materials}

High activity dry yeast was purchased from angel yeast company. The yeast cell were grown in YPD medium (1\% yeast extract, $2 \%$ Bacto-peptone, $2 \%$ glucose, $\mathrm{pH} 5.6)$ at $35^{\circ} \mathrm{C}$ with constant shaking (140 rpm), under aerobic condition.

Chlorothalonil was purchased from commerical sources and was prepared by dissolving 100 $\mu \mathrm{g} \cdot \mathrm{mL}^{-1}$ in water, which was then added to the medium at the concentrations indicated. The heavy metals used were ultrapure salts $\left(\mathrm{CuSO}_{4} \cdot 5 \mathrm{H}_{2} \mathrm{O}, \mathrm{PbCl}_{2}, \mathrm{CdCl}_{2}, \mathrm{HgSO}_{4}\right.$ and $\left.\mathrm{K}_{2} \mathrm{Cr}_{2} \mathrm{O}_{7}\right)$. All chemical were of analytical grade. The other reagents were of reagent grade and purchased from commerical sources.

\subsection{Yeast culture}

$0.1 \mathrm{~g}$ of active dry yeast powder was placed in $100 \mathrm{~mL}$ sterile water for $20 \mathrm{~min}$ at $35^{\circ} \mathrm{C}$. The activated yeast were grown overnight in $100 \mathrm{~mL}$ of YPD medium at $35{ }^{\circ} \mathrm{C}$. The cell were harvested, centrifuged and washed, and then suspended in in a $100 \mathrm{~mL}$ fresh liquid medium. Then the $\mathrm{OD}_{600}$ value of the yeast liquid culture medium was measured by Ultraviolet visible spectrophotometry ( UV-VIS, L5S, China) every two hours and finish after $24 \mathrm{~h}$.

Yeast cells were harvested by centrifuging $5 \mathrm{~mL}$ aliquots of culture at $3,000 \mathrm{rpm} 5 \mathrm{~min}$, removing the supernatant and washing the resulting cell pellets three times in $0.9 \%(\mathrm{w} / \mathrm{v}) \mathrm{NaCl}$ solution. Finally the cells were resuspended in saline for use [13].

\subsection{Growth assays}

To evaluate the effect of chlorothalonil on the growth of the yeasts, cells were suspended in $10 \mathrm{~mL}$ YPD medium to give an OD of 0.4 at $600 \mathrm{~nm}$, and incubated time $4 \mathrm{~h}$ in various concentrations of chlorothalonil $\left(0 \mu \mathrm{g} \mathrm{mL}^{-1}-0.4 \mu \mathrm{g} \mathrm{mL}^{-1}\right)$. Lately The cell growth was monitored turbidometry at $600 \mathrm{~nm}$. Each treatment was carried out in triplicate. In addition, the cell inhibition rate (IR)was calculated as following:

$$
I R=\left(1-\frac{O D_{600(T)}-O D_{600(B)}}{O D_{600(C)}-O D_{600(B)}}\right) \times 100 \%
$$

IR : cell inhibition rate(\%); $\mathrm{OD}_{600(\mathrm{~T})}$ : the $\mathrm{OD}_{600}$ value of yeast cells in YPD medium which containing chlorothalonil; $\mathrm{OD}_{600(\mathrm{~B})}$ : the $\mathrm{OD}_{600}$ value of yeast cells in YPD medium is $0.4 ; \mathrm{OD}_{600(\mathrm{C})}$ : the $\mathrm{OD}_{600}$ value of yeast cells in YPD medium.

\subsection{The influence of culture conditions on yeast cell sensitivity to chlorothalonil}

According to the preliminary experimental results, the action time, $\mathrm{pH}$ and temperature were taken as three single factors, and five levels were set as shown in table 1 . The yeast $\mathrm{OD}_{600}$ was determined respectively. Each treatment was carried out in triplicate. 


\begin{tabular}{cccccccc}
\hline Single factor & Symbol & \multicolumn{3}{c}{ Level } \\
\hline Action time $(\mathrm{h})$ & $\mathrm{A}$ & 2 & 3 & 4 & 5 & 6 & \\
& $\mathrm{~B}$ & 3 & 4 & 5 & 6 & 7 & \\
The initial $\mathrm{pH}$ value of medium & $\mathrm{C}$ & 20 & 30 & 40 & 50 & 60 \\
Temperature $\left({ }^{\circ} \mathrm{C}\right)$ & & & & & & \\
\hline
\end{tabular}

\subsection{Sensitivity of yeast to chlorothalonil was analyzed by response surface method}

The response surface test was designed based on the results of the above single-factor test. The level of design factors is shown in table 2.

Table 2 Factor level coding table

\begin{tabular}{cccc}
\hline Level & & Factor & \\
\cline { 2 - 4 } & A & B & C \\
\hline-1 & 3 & 3 & 30 \\
0 & 4 & 4 & 40 \\
1 & 5 & 5 & 50 \\
\hline
\end{tabular}

\subsection{The sensitivity of optimized yeast to chlorothalonil}

The yeast cells treated under the optimal culture conditions were suspended in YPD medium to give an OD of 0.4 at $600 \mathrm{~nm}$, and incubated $4 \mathrm{~h}$ in various concentrations of chlorothalonil ( 0

$130 \mu \mathrm{g} \cdot \mathrm{mL}^{-1}$ to $0.012 \mu \mathrm{g} \cdot \mathrm{mL}^{-1}$ ). Each treatment was carried out in triplicate, and the $\mathrm{OD}_{600}$ and the cell IR after $4 \mathrm{~h}$ exposure was calculated.

\subsection{The influence of optimized conditions on yeast cell}

The yeast cells treated under optimal culture conditions, were centrifuged at $3000 \mathrm{rpm} 5 \mathrm{~min}$, and the precipitate was washed twice with aseptic PBS, while the untreated cells as control.

\subsubsection{Morphology}

The morphological changes of the yeast cells $\left(1 \times 10^{5}\right)$ were analyzed using light microscope(NE610,China ) at $1000 \times$ and scanning electron microscope (SEM) at $50000 \times$.

\subsubsection{Cell membrane integrity}

Cell membrane integrity was determined using lactate dehydrogenase (LDH) release assay

140 kit. The cells were inoculated on the 96-well plate. Each culture hole was divided into four groups: the cell-free culture hole, the untreated control group, the untreated maximum enzyme activity control hole for subsequent cleavage, and the treated cell hole. The untreated cells were performed with $10 \%(\mathrm{~W} / \mathrm{V})$ reagent that releases $\mathrm{LDH}$ and used as a control group for maximum enzyme activity. LDH detection working fluid was added to each well and incubated in dark for 30min.

145 The samples were read at $490 \mathrm{~nm}$ in a microplate reader ( Readmax 1900,China ).

\subsubsection{DHE staining}

The reactive oxygen species (ROS) of yeast cells were measured by ROS assay kit that includes dihydroethidium (DHE). The yeast cells were treated with $5 \mu \mathrm{g} \cdot \mathrm{ml}^{-1}$ DHE probe. Images of cells were captured using $40 \times$ objectives under fluoresent microscope. The accumulation of 
150 ROS in the cells was determined according to the intensity of fluorescence intensity.

\subsubsection{DNA fragmentation}

The yeast DNA was extracted from Ezup column yeast genomic DNA extraction kit and placed in $1.5 \%$ agarose gel electrophoresis apparatus on $120 \mathrm{~V}$ for $1.5 \mathrm{~h}$. DNA fragmentation was detected by gel imager. The cells were divided into three group: the untreated control group, the heat death yeast cell group, and the treated yeast cell group.

\subsubsection{Capase 3 enzymatic activity}

The protease activity of caspases 3 in yeast cells was performed utilizing a colorimetric assay kit. The resulting cells $\left(2 \times 10^{6}\right)$ was lysed with $100 \mu \mathrm{L}$ cold lysis buffer and inculbated on ice for $0.5 \mathrm{~h}$. The resulting cell lysate was centrifuged at $10000 \mathrm{rpm}$ for $10 \mathrm{~min}$ and the suspernatant was collected. The activity of caspase 3 was measured immediately. The samples were read at $405 \mathrm{~nm}$ in a microplate reader.

2.8. Chemeical analysis and bioassays of the heavy metal waste water samples by yeast cells biosensor

Repeat test method 2.6 to detect heavy metal $\mathrm{Cu}^{2+}, \mathrm{Pb}^{2+}, \mathrm{Hg}^{2+}, \mathrm{Cr}^{6+}$ and $\mathrm{Cd}^{2+}$. Meanwhile, the waste water samples were filtered a $0.22 \mu \mathrm{m}$ pore-size membrane filter, acidified by nitric acid before the measurement of heavy metals by Inductively Coupled Plasma Optical Emission Spectrometer (Agilent ICP-OES 5110, America). The test methods were carried out according to standard protocol(Method of determination for 26 elements (copper, nickel, lead, zinc, cadmium, chrome etc.) content in the sludge from industrial waste liquid treatment. GB/T 36690-2018).

\subsection{Statistical analysis}

Data analysis was performed using software Origin 8、SPSS 13.0 and MATLAB 2016. LSD method was used for comparison between the treatment group and the control group, and $P<0.05$ was defined as the difference. "*, $* * "$ respectively means $P<0.05, P<0.01$.

\section{Results and disscussion}

\subsection{The growth curve of yeast}

Fig. 1 indicates the growth curve of the yeast. As can be seen from it, $0 \sim 6 \mathrm{~h}$ was the lag phase of yeast, $6 \sim 16 \mathrm{~h}$ was the logarithmic phase of yeast, and especially $10 \mathrm{~h}$ was the middle timing of the logarithmic phase. After $14 \mathrm{~h}$, yeast entered stationary phase and the growth curve tended to be stable. At $10 \mathrm{~h}$, yeast cells had a strong ability to proliferate. Scariot et al also choose to culture yeast cells in this phase when studying the toxicity of dithianon to yeast cells[22]..Moreover, Wang et al show that the Psychrobacter sp. at the middle of logarithmic phase or transition from logarithmic to stationary phase would have a higher sensitivity to toxicants beasuse the phase would a strong growth rate and a higher metabolism. Therefore, yeast at $10 \mathrm{~h}$ was selected for subsequent experiments. 


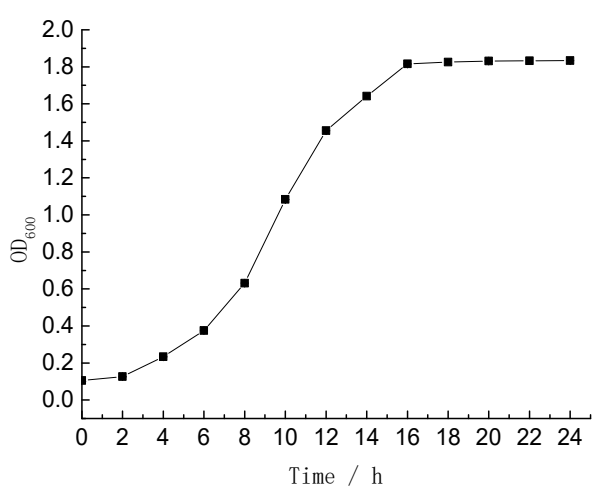

Fig. 1 Growth curve of yeast in YPD medium

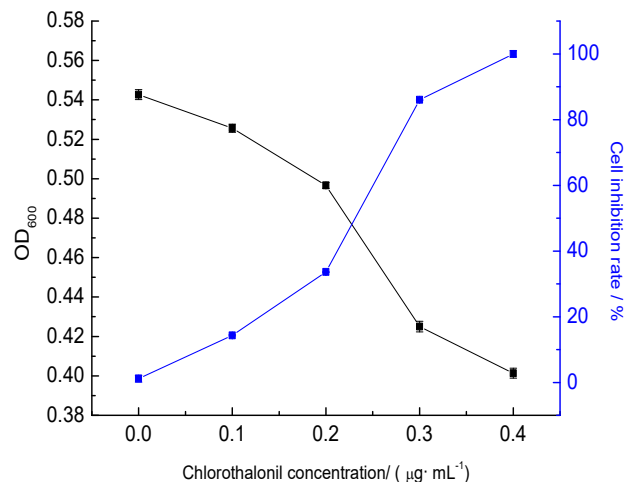

Fig. 2 The effect of chlorothalonil on the growth of yeast

\subsection{The effect of chlorothalonil on yeast proliferation}

The toxicity of chlorothalonil on the proliferation of yeast strains, cells were grown in YPD medium, containing 0 to $0.4 \mu \mathrm{g} \cdot \mathrm{mL}^{-1}$. The cell growth was measured by monitoring the optical density at $600 \mathrm{~nm}$. Meanwhile, according to test method 2.6, cell inhibition rates were also calculated. In figure 2, as for the cell growth curve, when the concentration of chlorothalonil was within the range of $0.4 \mu \mathrm{g} \cdot \mathrm{mL}^{-1}$, the $\mathrm{OD}_{600}$ value of the yeast solution decreased with the increase of the concentration of chlorothalonil, indicating that the intensity of chlorothalonil inhibiting the proliferation of yeast increased with the increase of the concentration. When the concentration of chlorothalonil was $0.2 \sim 0.3 \mu \mathrm{g} \cdot \mathrm{mL}^{-1}$, the $\mathrm{OD}_{600}$ of yeast solution decreased the fastest. When the concentration of chlorothalonil was $0.4 \mu \mathrm{g} \cdot \mathrm{mL}^{-1}$, the $\mathrm{OD}_{600}$ value of yeast solution did not change significantly compared with the initial concentration of bacteria solution, indicating that chlorothalonil almost completely inhibited the proliferation of yeast. In addition, cell inhibition rate increased with increasing concentration of chlorothalonil. Therefore, chlorothalonil has toxicity on yeast growth and inhibition rate, and present dosage dependence relations. The $\mathrm{EC}_{50}$ value, which represents the concentration of chlorothalonil that cause $50 \%$ inhibition of the growth rate, is about $0.25 \mu \mathrm{g} \mathrm{mL} \mathrm{m}^{-1} .0 .4 \mu \mathrm{g} \mathrm{mL} \mathrm{m}^{-1}$ of chlorothalonil exerted the maximum inhibitory effect on yeast cell. $0.3 \mu \mathrm{g} \cdot \mathrm{mL}^{-1}$ of chlorothalonil produced $87 \%$, which is close to $100 \%(0.4$ $\mu \mathrm{g} \cdot \mathrm{mL}^{-1}$ ). Considering the cost, the addition amount of chlorothalonil was chosen as $0.3 \mu \mathrm{g} \cdot \mathrm{mL}^{-1}$ in subsequent experiments.

\subsection{Response surface analysis of yeast detection sensitivity}

According to the results of the above single-factor experiment, the response surface optimization experiment was designed, and the results were shown in Table 3.

Table 3 Experimental results of response surface method

\begin{tabular}{ccccc}
\hline Run & A & B & C & Decrease of OD 600 value \\
\hline 1 & -1 & -1 & 0 & 0.195 \\
2 & 1 & -1 & 0 & 0.192 \\
3 & -1 & 1 & 0 & 0.196 \\
4 & 1 & 1 & 0 & 0.181 \\
5 & -1 & 0 & -1 & 0.163
\end{tabular}




$\begin{array}{lllll}6 & 1 & 0 & -1 & 0.152 \\ 7 & -1 & 0 & 1 & 0.168 \\ 8 & 1 & 0 & 1 & 0.168 \\ 9 & 0 & -1 & -1 & 0.156 \\ 10 & 0 & 1 & -1 & 0.155 \\ 11 & 0 & -1 & 1 & 0.165 \\ 12 & 0 & 1 & 1 & 0.159 \\ 13 & 0 & 0 & 0 & 0.214 \\ 14 & 0 & 0 & 0 & 0.215 \\ 15 & 0 & 0 & 0 & 0.212 \\ 16 & 0 & 0 & 0 & 0.214 \\ 17 & 0 & 0 & 0 & 0.213\end{array}$

Design Expert 8.05 software was used to regression fit the response surface test results, and the quadratic multiple regression model equation was obtained: $Y=-0.8308+0.0718 a+0.1243 b$ $+0.0331 c-0.003 a b+0.0003 a c-0.0001 b c-0.009 a^{2}-0.0133 b^{2}-4.1550 c^{2}$, and the results were shown in Table 4. The model $\mathrm{P}<0.01$, the missing item $\mathrm{P}=0.1104>0.05$, the correlation coefficient $\mathrm{R}^{2}=99.78 \%$. The results show that the model fits well. $\mathrm{CV}$ was $0.93 \%$, indicating that the test results were feasible. Therefore, the test results could be analyzed and predicted.

Table 4 Analysis of variance model of regression equation

\begin{tabular}{|c|c|c|c|c|c|c|}
\hline Source & Sum of squares & DF & mean square & $F$ value & $\mathrm{P}($ Prob $>\mathrm{F})$ & significant \\
\hline Model & 0.0030 & 9 & 0.0003 & 353.16 & $<0.0001$ & $* *$ \\
\hline A & 0.0000 & 1 & 0.0000 & 35.98 & 0.0005 & $* *$ \\
\hline B & 0.0000 & 1 & 0.0000 & 12.37 & 0.0098 & $* *$ \\
\hline $\mathrm{C}$ & 0.0001 & 1 & 0.0001 & 49.46 & 0.0002 & $* *$ \\
\hline $\mathrm{AB}$ & 0.0000 & 1 & 0.0000 & 12.32 & 0.0099 & $* *$ \\
\hline $\mathrm{AC}$ & 0.0000 & 1 & 0.0000 & 10.35 & 0.0147 & $*$ \\
\hline $\mathrm{BC}$ & 0.0000 & 1 & 0.0000 & 2.14 & 0.1870 & \\
\hline $\mathrm{A}^{2}$ & 0.0005 & 1 & 0.0005 & 124.65 & $<0.0001$ & $* *$ \\
\hline $\mathrm{B}^{2}$ & 0.0008 & 1 & 0.0008 & 254.94 & $<0.0001$ & $* *$ \\
\hline $\mathrm{C}^{2}$ & 0.0012 & 1 & 0.0012 & 2488.19 & $<0.0001$ & $* *$ \\
\hline Residual & 0.0000 & 7 & 0.0000 & & & \\
\hline Lack of fit & 0.0000 & 3 & 0.0000 & 3.91 & 0.1104 & \\
\hline Pure error & 0.0000 & 4 & 0.0000 & & & \\
\hline Total & 0.0030 & 16 & & & & \\
\hline
\end{tabular}

In Table $4, \mathrm{~A}, \mathrm{~B}, \mathrm{C}, \mathrm{AB}, \mathrm{A}^{2}, \mathrm{~B}^{2}$ and $\mathrm{C}^{2}$ show significant differences, and $\mathrm{AC}$ interaction show significant differences. The response surface analysis of the regression model was conducted with design-expert software, and the results were shown in Fig 3, Fig 4, and Fig 5. The Optimization 
module of the software was used to optimize the culture conditions. When the predicted action time was $3.95 \mathrm{~h}$, the initial $\mathrm{pH}$ value was 3.97 , and the culture temperature was $40.42^{\circ} \mathrm{C}, \mathrm{OD}_{600}$ decreased by 0.2141 . According to the actual test conditions, the temperature was adjusted to $40.4^{\circ} \mathrm{C}$, yeast was cultured under the above optimal conditions, and three parallel experiments were conducted. The actual $\mathrm{OD}_{600}$ decrease average value was 0.2139 . The experimental results were close to the predicted value, which proved that the regression model could better predict the influence of culture conditions on the sensitivity of yeast to detect chlorothalonil.
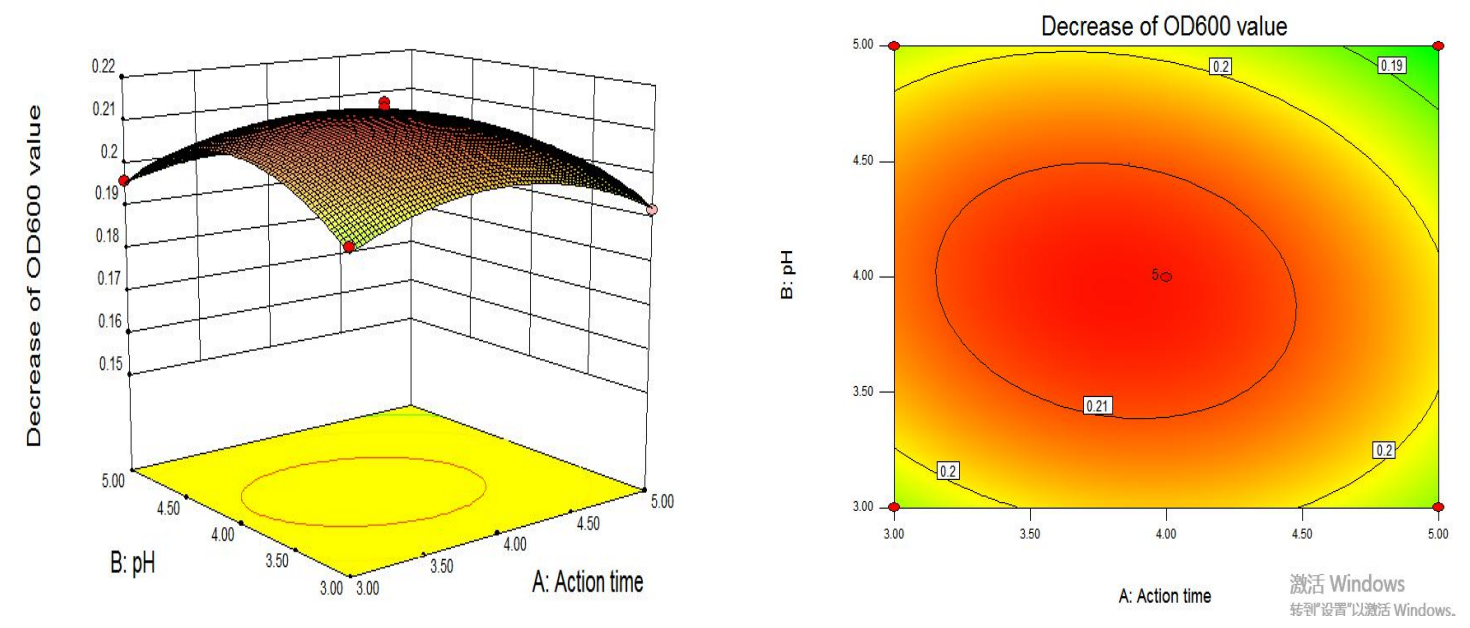

Fig. 3 The effect of action time and $\mathrm{pH}$ on sensitivity of yeast detection
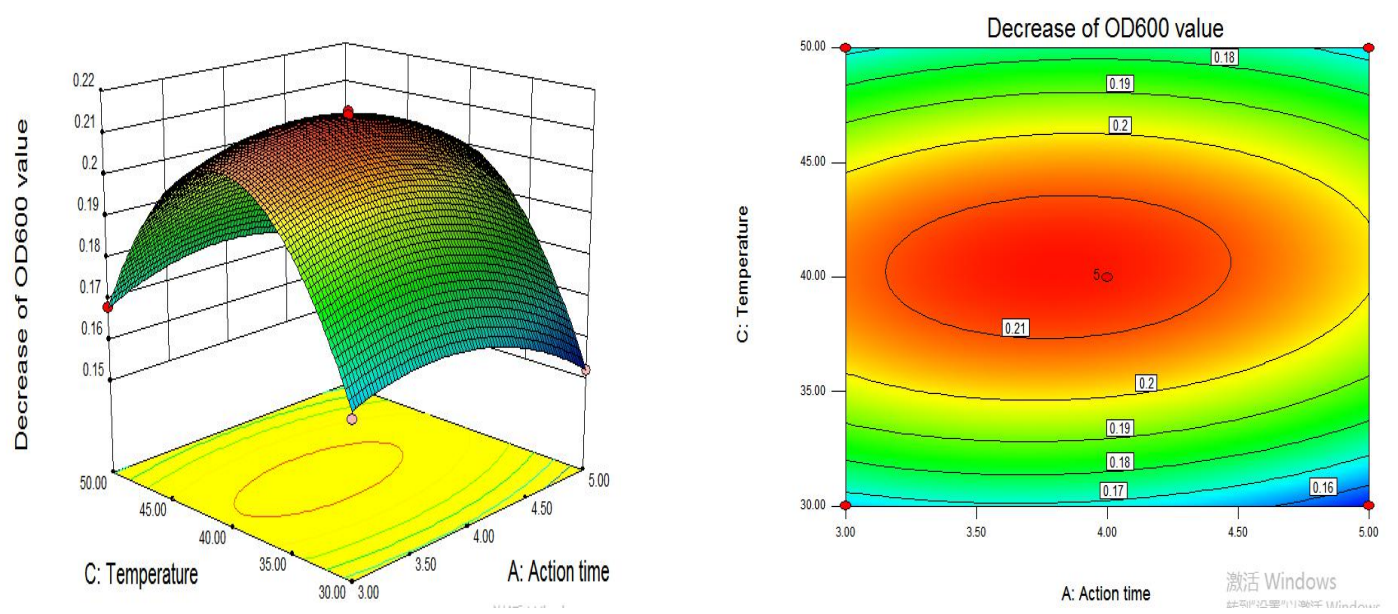

Fig. 4 The effect of time and temperature on sensitivity of yeast detection 

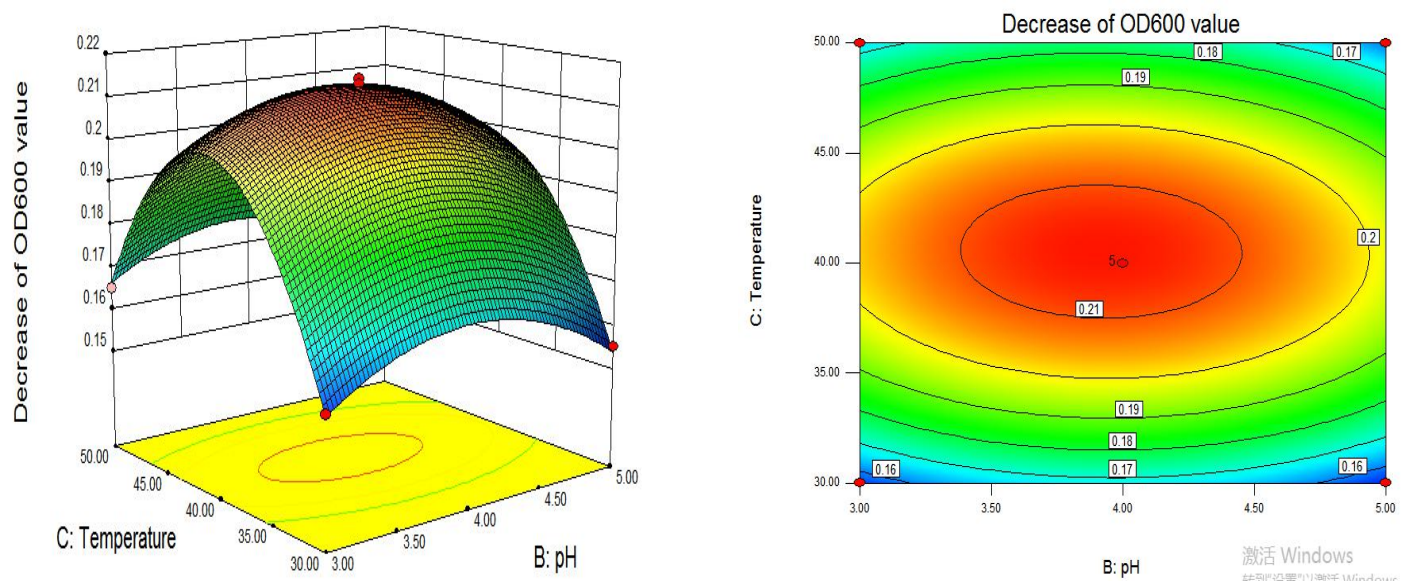

Fig. 5 The effects of $\mathrm{pH}$ and temperature on sensitivity of yeast detection

\subsection{The sensitivity of yeast detection under optimal response surface conditions}

The optimal experimental conditions obtained from the response surface were as following: the action time was $3.95 \mathrm{~h}$, the initial $\mathrm{pH}$ of the medium was 3.97, and the culture temperature was $40.4{ }^{\circ} \mathrm{C}$. Yeast was cultured and its sensitivity to the detection of chlorothalonil was measured, which were as shown in Fig 6. The concentration of chlorothalonil was within the range of 0 $\mu \mathrm{g} \cdot \mathrm{mL}^{-1} \sim 0.004 \mu \mathrm{g} \cdot \mathrm{mL}^{-1}$, and the $\mathrm{OD}_{600}$ value began to decrease. Chlorothalonil had an inhibitory effect on the proliferation of yeast. When the concentration of chlorothalonil was between 0.004 $\mu \mathrm{g} \cdot \mathrm{mL}^{-1}-0.008 \mu \mathrm{g} \cdot \mathrm{mL}^{-1}$, the $\mathrm{OD}_{600}$ value decreased significantly, and the intensity of chlorothalonil's effect on yeast cell proliferation gradually increased. The $\mathrm{EC}_{50}$ value represents the concentration of chlorothalonil that caused $50 \%$ inhibition of the growth rate. Compared the $\mathrm{EC}_{50}$ value of the untreated yeast cell, it is easy found that the $\mathrm{EC}_{50}$ value of yeast on chlorothalonil decreased from $0.25 \mu \mathrm{g} \cdot \mathrm{mL}^{-1}$ to $0.006 \mu \mathrm{g} \cdot \mathrm{mL}^{-1}$ (Fig. 2 and Fig. 6 ), which indicated that the sensitivity of yeast to chlorothalonil could be improved after culture.

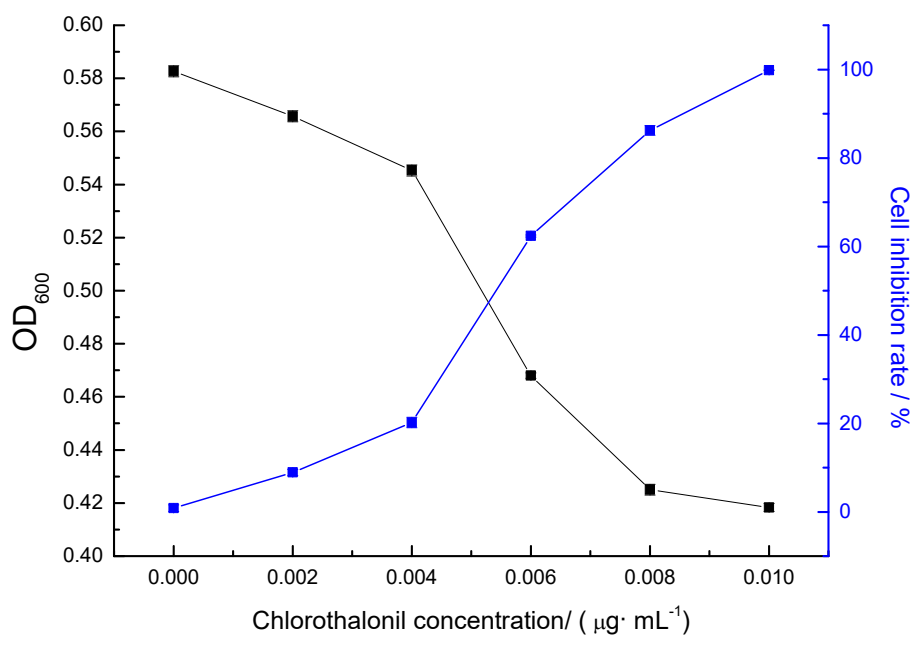

Fig. 6 The effects of chlorothalonil on yeast growth 
bioRxiv preprint doi: https://doi.org/10.1101/2020.01.07.898106; this version posted January 9, 2020. The copyright holder for this preprint (which was not certified by peer review) is the author/funder, who has granted bioRxiv a license to display the preprint in perpetuity. It is made available under aCC-BY-NC 4.0 International license.

\subsubsection{Morphology}

In order to explore the influence of optimized culture conditions on the internal structure of yeast cells, the optimized yeast cells were observed with a optical microscope and SEM (Fig. 7). In control group, the internal structure of control cells was relatively complete, fat particles accumulated in large quantities, and cells hardly had vesicles. But under the optimal culture condition, the cell fat granule was decreased in the internal structure, and the percentage of cavitation was significantly increased (Fig. 8). In addition, the overall transparency of the cell was significantly improved.

A
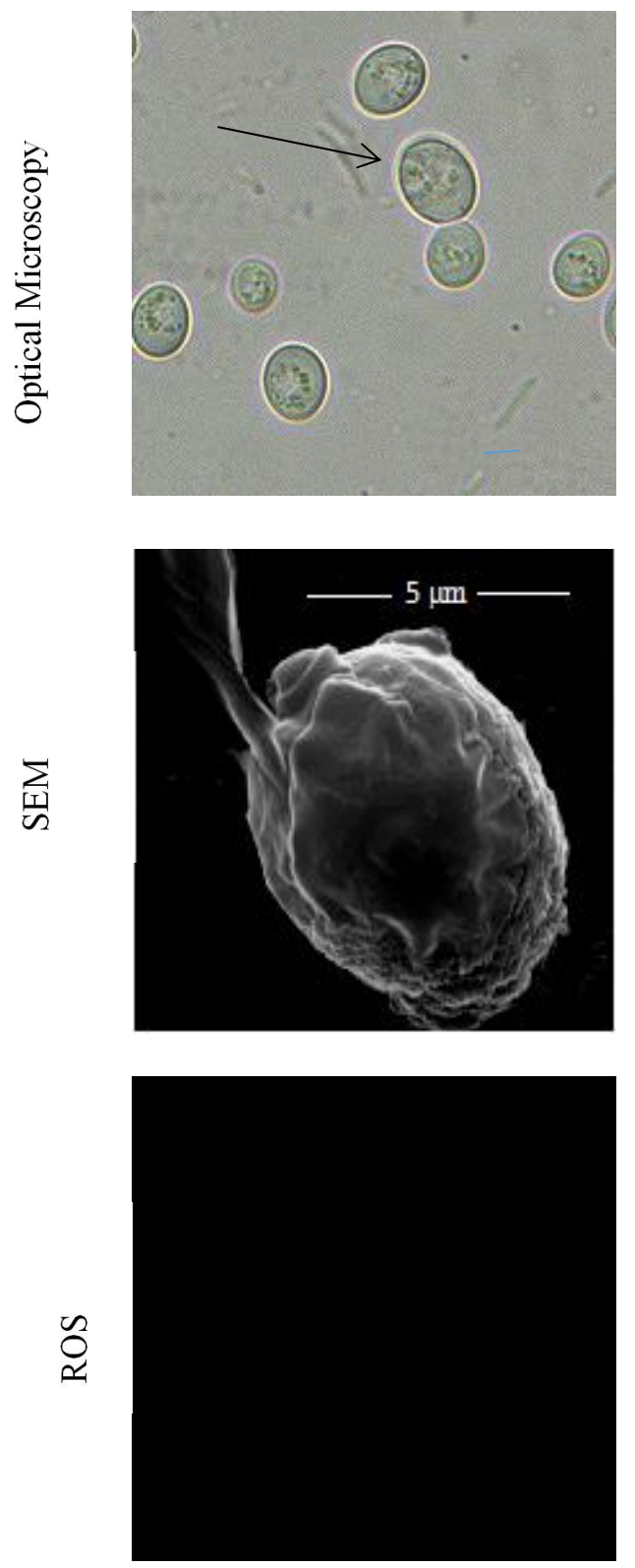

B
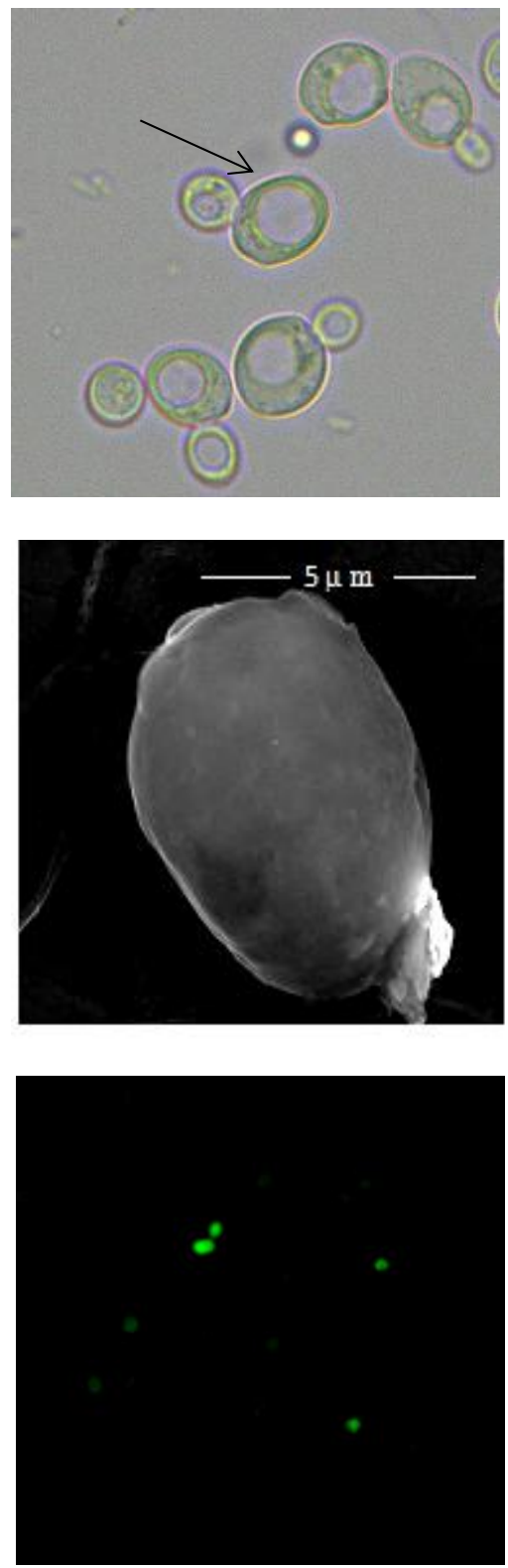

Fig. 7 Effects of optimized culture conditions on the internal structure of yeast cells. The cells were grown under aerobic condition. Aliquots were taken at the indicated time. A, yeast cells in YPD medium at $35^{\circ} \mathrm{C}$; 


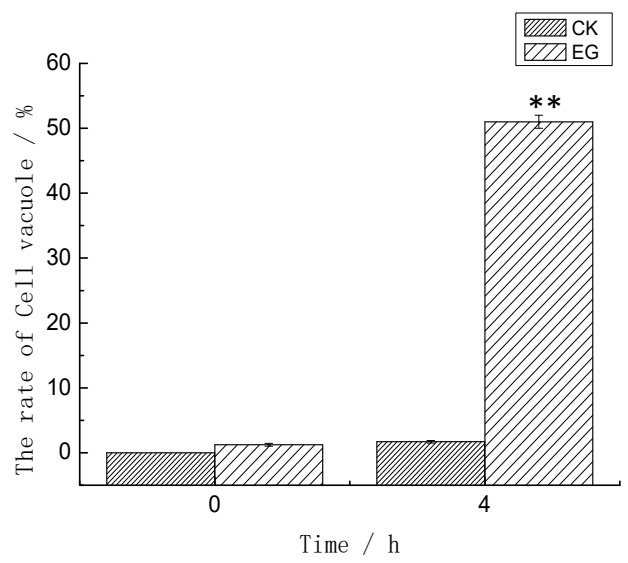

Fig. 8 Effects of optimized culture conditions on the Internal Structure

At the same time, the cells were also observed by SEM (Fig.7). In control group, the surface folds and villi of yeast cells were obvious. But in the optimum culture conditions of experimental group, the surface of yeast cells were smooth and no fold, and bacteria shape was from round to oval, for the reason that the yeast cells maybe morbid, and cell wall maybe thinner or more loose structure, and cell membrane permeability could increase, which leading that intracellular and extracellular harmful substances are more likely to enter the bacteria cause more damage, reduce the cell internal structure, and then cells become more fragile. The vesicle occurs the phenomenon with acetic acid in yeast cells consistent with the experimental results and internal microstructure morphology [22]. Therefore, it is useful that changing yeast culture conditions in a certain extent would improve the sensitivity of chlorothalonil yeast cells.

\subsubsection{Measure of ROS generation}

In order to determine to the possible association of ROS in optimized conditions-induced cavitation, the ROS of yeast cells was measured to using fluorescent probe DHE in the present study. As shown in Fig. 7, in control, no observable fluorescence images were found. However, after yeast cells were treated under optimized culture conditions, some bright green fluorescence cells were easily observed, which is because intracelluar ROS level increased. When the ROS generation is lower than the threshold, it will cause apoptosis, and when the threshold is exceeded, it will cause death. In apoptosis the increased ROS would result in decreased mitochhondrial permeability. In apoptosis, the increased ROS would result in decreased mitochhondrial permeability, which indirectly leaded to increased capase 3 activity.

\subsubsection{DNA fragmentation}

DNA ladder of yeast cells was a characteristic of apoptosis. In the present study, to further distinguish the treated yeast cells between apoptosis or necrosis. The yeast DNA was extracted and placed in $1.5 \%$ agarose gel electrophoresis apparatus on $120 \mathrm{~V}$ for $1.5 \mathrm{~h}$. DNA fragmentation was detected by gel imager. As shown in Fig. 9, in control, DNA electrophoresis band consists of only one large molecular fragment, DNA electrophoresis bands of heat death cells were diffuse without visible, and DNA electrophoresis bands of treatment yeast cells was ladder, which is due to the action of endonuclease. 


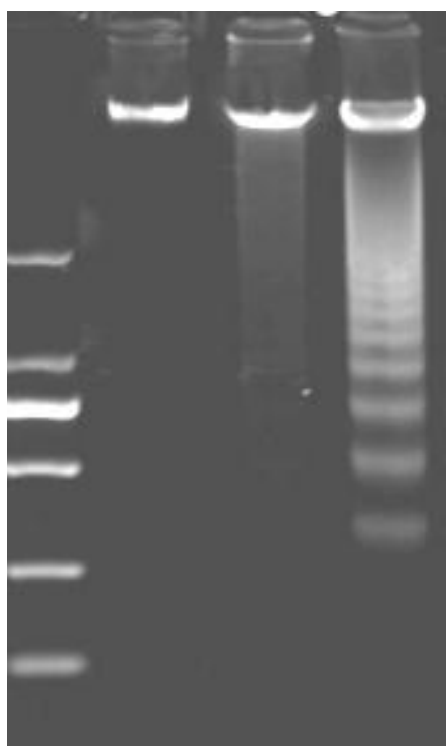

Fig. 9. DNA electrophoresis band. 2000 bp DNA ladder (lane 1), DNA extracted from control group (lane 2 ), DNA extracted from heat death group (lane 3), DNA extracted from treated group ( lane 4).

\subsubsection{Caspase 3 activity}

To investigate the involvement of caspase signaling cascade in optimized conditions-induced apoptosis, yeast cells were treated under optimized conditions and caspase 3 enzymatic was determined. Compared to control groups, caspased 3 of the treatment was much higher(Table 5). In apoptosis, caspase would result in cavitation. The phenomenon was according to the results of the morphology.

Table 5 Caspase 3 activity unit of yeast cell

\begin{tabular}{cccc}
\hline Group & $\mathrm{A}_{405}$ & $\mathrm{pNA} / \mu \mathrm{M}$ & Caspase 3 activity unit $/ \mathrm{U}$ \\
\hline Control & 0.0419 & 0.901 & 0.901 \\
Treat & 0.088 & 42.43 & 42.43 \\
\hline
\end{tabular}

Taken together, the results confirm that the treatment group of optimized conditions increased ROS generation, which stimulated caspase 3 activity with cavaitation and induced apopotosis with DNA ladder, which were also verified that the effective inhibition concentration of chlorothalonil against yeast increased from $0.25 \mu \mathrm{g} \cdot \mathrm{mL}^{-1}$ to $0.006 \mu \mathrm{g} \cdot \mathrm{mL}^{-1}$, which increased by 41.67 times.

3.6 Toxicities of heavy metal to yeast cells of optimized conditions

In order to verify the optimization can be used as a harmful material detection sensitivity, the important heavy metal pollutants, such as $\mathrm{Cu}^{2+}, \mathrm{Cd}^{2+}, \mathrm{Pb}^{2+}, \mathrm{Hg}^{2+}, \mathrm{Cd}^{6+}$ were respectively investigated under the optimal experimental conditions in present study. The responses of yeast cell based biosensor to the heavy metal ions were shown in Table 6 . The $\mathrm{EC}_{50}$ results obtained were compared with those of published data by other methods (Table 6). As shown in Table 6, the $\mathrm{EC}_{50}$ values of toxicity assay based on yeast cells were comparable and even better than those of other tests. The results were similar to Wang et al.'s report on toxicity order of heavy metals based on Psychrobacter sp. biosensor. Analysis of the reason may be due to different methods. Those toxicity assays were used electricall and optical real-time response for toxicity[20]. As for $\mathrm{Hg}^{2+}$, it s much lower toxicity than other heavy metals was mainly due to its stronger membrane sequestration. Moreover, according to the $4 \mathrm{~h}-\mathrm{EC}_{50}$ value of the five measured heavy metals to yeast cell biosensor, the toxicity was in order of $\mathrm{Cd}^{2+}>\mathrm{Cu}^{2+}>\mathrm{Pb}^{2+}>\mathrm{Cr}^{6+}>\mathrm{Hg}^{2+}$. The toxicity of $\mathrm{Cd}^{2+}$ is strong, because $0.5 \mu \mathrm{g} \cdot \mathrm{mL}^{-1}$ of $\mathrm{Cd}^{2+}$ could inhibition $50 \%$ of growth of yeast cells. However, Cui 
et al report that $\mathrm{Hg}^{2+}$ is strong in the toxicity[23]. Therefore, there was some significant difference in the sensitivities of the various tests and methods, which reflected the fact that each bacterial species and test procedure had its own sensitivity pattern to toxicants.

Table 7 Comparison of $\mathbf{E C}_{50}$ value by toxicity assays to others

\begin{tabular}{lcccccc}
\hline \multirow{2}{*}{ Toxicity assays } & \multicolumn{3}{c}{ Toxicants, $\mathrm{EC}_{50}\left(\mu \mathrm{g} \cdot \mathrm{mL}^{-1}\right)$} & \multirow{2}{*}{ References } \\
\cline { 2 - 6 } & $\mathrm{Cu}^{2+}$ & $\mathrm{Cd}^{2+}$ & $\mathrm{Pb}^{2+}$ & $\mathrm{Hg}^{2+}$ & $\mathrm{Cr}^{6+}$ & \\
\hline Yeast cells bionsensor, incubation time $4 \mathrm{~h}$ & 2.1 & 0.5 & 2.8 & 3 & 2.5 & Present study \\
\hline Acinetobater baylyi Tox2 biosensor, incubation time $15 \mathrm{~min}$ & - & 43.67 & - & 0.12 & - & Cui et al., 2018 \\
\hline M. Chula fish, exposure time $96 \mathrm{~h}$ & 0.68 & 39.83 & - & 0.14 & - & Cui et al., 2018 \\
\hline Psychrobacter sp. biosensor, incubation $30 \mathrm{~min}$ & 2.6 & 47.3 & 110.1 & 0.8 & 14 & Wang et al., 2013 \\
\hline FM-TOX, E.coli, incubation time $60 \mathrm{~min}$ & 3.7 & 7.8 & 20.4 & 2.0 & - & Catterall et al., 2010 \\
\hline
\end{tabular}

As shown in Table 7 and Fig. 10. The $\mathrm{OD}_{600}$ value of the yeast solution decreased with increasing concentration of $\mathrm{Cu}^{2}, \mathrm{Cd}^{2}{ }^{+}, \mathrm{Pb}^{2}{ }^{+}, \mathrm{Hg}^{2}{ }^{+}$, and $\mathrm{Cd}^{6+}$ and exhibited a significant correlation with the following concentration of $\mathrm{Cu}^{2+}\left(0 \mu \mathrm{g} \cdot \mathrm{mL}^{-1}-4 \mu \mathrm{g} \cdot \mathrm{mL}^{-1}\right), \mathrm{Cd}^{2+}\left(0 \mu \mathrm{g} \cdot \mathrm{mL}^{-1}-0.08\right.$ $\left.\mu \mathrm{g} \cdot \mathrm{mL}^{-1}\right), \mathrm{Pb}^{2+}\left(0 \mu \mathrm{g} \cdot \mathrm{mL}^{-1}-4 \mu \mathrm{g} \cdot \mathrm{mL}^{-1}\right), \mathrm{Hg}^{2+}\left(0 \mu \mathrm{g} \cdot \mathrm{mL}^{-1}-8 \mu \mathrm{g} \cdot \mathrm{mL}^{-1}\right)$, and $\mathrm{Cd}^{6+}\left(0 \mu \mathrm{g} \cdot \mathrm{mL}^{-1}-6 \mu \mathrm{g} \cdot \mathrm{mL}^{-1}\right)$.

340 The calibration cures were shown in table 6 , which $\mathrm{x}$ was toxicants' concentration and $\mathrm{y}$ was absorbance. It is found that the method using yeast cell biosensor has a strong correlation in toxicity test for five heavy metals. Moreover, The ICP-OES methods were carried out according to standard protocol(GB/T 36690-2018). There was also significant correlation between the signal value (CPS) of internal standard elements and the concentrations of measured elements(data no shown). Even though the working curve of ICP-OES is high significant, the method can not detect the cytotoxicity[]. In this case, the yeast cell biosensor would make it a good method to detect cytotoxicity of heavy metals in waste water , such as $\mathrm{Cu}^{2+}, \mathrm{Cd}^{2+}, \mathrm{Pb}^{2+}, \mathrm{Hg}^{2+}$, and $\mathrm{Cd}^{6+}$.
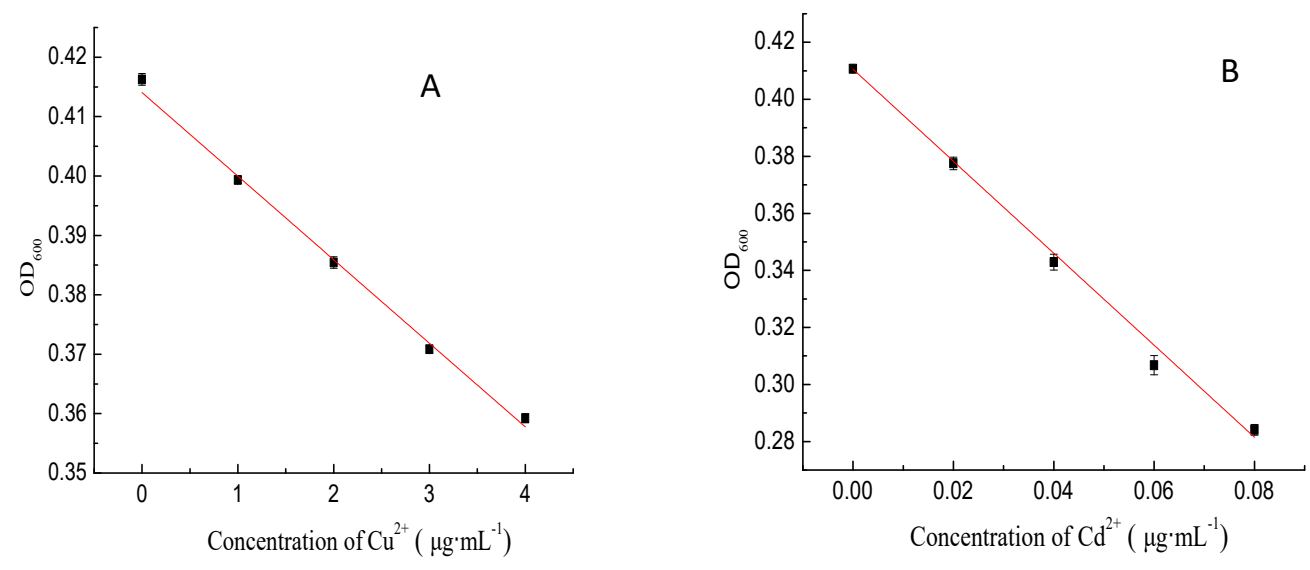

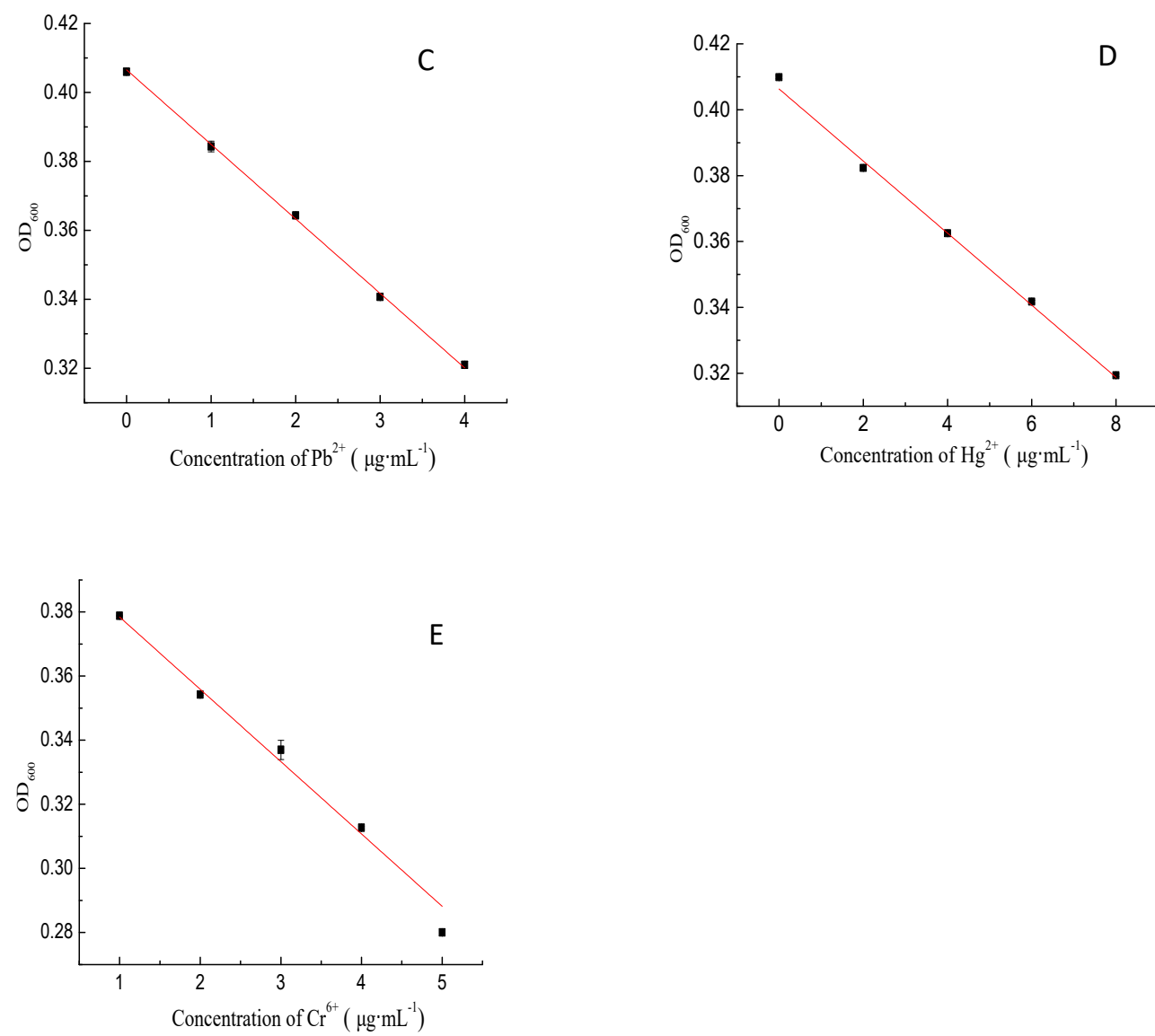

Fig. 10. Regression of yeast cell biosensor under different concentrations of $\mathrm{Cu}^{2+}(\mathrm{A})$, $\mathrm{Cd}^{2+}(\mathrm{B}), \mathrm{Pb}^{2+}(\mathrm{C}), \mathrm{Hg}^{2+}(\mathrm{D}), \mathrm{Cr}^{6+}(\mathrm{E})$.

Table 8 The results of toxicities of heavy metal to yeast cell biosensor

\begin{tabular}{ccccccc}
\hline Toxicants & $\begin{array}{c}\text { Range } \\
\left(\mu \mathrm{g} \cdot \mathrm{mL}^{-1}\right)\end{array}$ & Regression & $\mathrm{R}^{2}$ & $\mathrm{p}$ & $\begin{array}{c}\mathrm{RSD} \\
(\%)\end{array}$ & $\begin{array}{c}\text { Recovery rate } \\
(\%)\end{array}$ \\
\hline $\mathrm{Cu}^{2+}$ & $0-4$ & $\mathrm{y}=-0.01394 \mathrm{x}+0.4561$ & 0.9938 & $<0.01$ & 0.15 & 101.11 \\
$\mathrm{Cd}^{2+}$ & $0-0.08$ & $\mathrm{y}=-1.499 \mathrm{x}+0.410$ & 0.9980 & $<0.01$ & 0.17 & 103.86 \\
$\mathrm{~Pb}^{2+}$ & $0-4$ & $\mathrm{y}=-0.0216 \mathrm{x}+0.40654$ & 0.9979 & $<0.01$ & 0.21 & 100.10 \\
$\mathrm{Hg}^{2+}$ & $0-8$ & $\mathrm{y}=-0.0096 \mathrm{x}+0.40378$, & 0.9960 & $<0.05$ & 0.14 & 100.54 \\
$\mathrm{Cr}^{6+}$ & $0-5$ & $\mathrm{y}=-0.02527 \mathrm{x}+0.4561$ & 0.9914 & $<0.01$ & 0.18 & 101.29 \\
\hline
\end{tabular}

The reproducibility of yeast cell biosensor was evaluated by six replicate assays for heavy metal ions $\mathrm{Cu}^{2+}, \mathrm{Cd}^{2+}, \mathrm{Pb}^{2+}, \mathrm{Hg}^{2+}$ and $\mathrm{Cr}^{6+}$ inhibition on yeast cell during $4 \mathrm{~h}$ incubation. The relative standard deviations (R.S.D.) obtained and the rate of recovery obtained were shown in table 8. Wang et al evaluated the reproducibility of the Psychrobacter sp. biosensensor by five heavy metals, $\mathrm{Cu}^{2+}, \mathrm{Cd}^{2+}, \mathrm{Zn}^{2+}, \mathrm{Cr}^{6+}$, which would inhibited on Psychrobacter sp. during $30 \mathrm{~min}$ incubation. The R.S.D. were $6.5 \%, 8.2 \%, 7.0 \%, 7.3 \%, 2.5 \%$, and $9.1 \%$, respectively. However, all of the R.S.D. of yeast cell biosensor by five heavy metals, $\mathrm{Cu}^{2+}, \mathrm{Cd}^{2+}, \mathrm{Zn}^{2+}, \mathrm{Cr}^{6+}$, which would inhibited on Psychrobacter sp. During $4 \mathrm{~h}$ incubation, were $0.15 \%, 0.17 \%, 0.21 \%, 0.14 \%$ and $0.18 \%$, respectively. It is easy fount that the R.S.D. are lower than the above. In addition, the recovery rate obtained were $101.11 \%, 103.86 \%, 100.10,100.54 \%, 101.29 \%$, respectively. Because 
the test data were in the range of $95 \%-105 \%$, which meet the requirement of recovery rate. Thus, the yeast cells biosensor showed a good, reproducible behavior and could be used for reproducible measurements. Moreover, with a portable and compact design, the yeast cells biosensor is able to monitor toxicity in different location.

Even though chemical analysis methods, such as ICP-MS and High Performance Liquid Choromatography (HPLC), have strengths in accuracy and limit of detection, it is impossible to evaluate the cytotoxicity and the biological effect of waste water by chemical result alone, and it is also expensive, prolix and complicated. However, the yeast cell biosensor is easy to operate, is sensitive to various toxicants, comparable to the other totxicity detection methods, is cheap in cost, and has. Therefore, the method which used yeast cells as biosensor will have great potential in the detection of the cytotoxicity of waste water in the future.

\section{Conclusion}

In this experiment, the culture condition, such as the action time, medium initial $\mathrm{pH}$, and temperature, could affect the yeast cells' sensitivity of chlorothalonil. Response surface methodology was used to increase the effects of culture conditions on yeast cells' sensitivity of chlorothalonil. There was the optimal culture conditions: the action time of $3.95 \mathrm{~h}$, medium initial $\mathrm{pH}$ value of 3.97 , culture temperature is $40.4{ }^{\circ} \mathrm{C}$. In this case, the $\mathrm{OD}_{600}$ decreased to 0.2141 , which is the maximum in all teats. The optimization of culture conditions for yeast detection sensitivity was validated, the actual $\mathrm{OD}_{600}$ dropped to 0.2139 , which was close to the predicted value. Thus the response surface test results more reliable. Under the optimal culture conditions, the $\mathrm{EC}_{50}$ value which responses inhibitory concentration of chlorothalonil on yeast cell decreased from $0.25 \mu \mathrm{g} \cdot \mathrm{mL}^{-1}$ to $0.006 \mu \mathrm{g} \cdot \mathrm{mL}^{-1}$ is due to many treated cells were apoptosis, which indicated that the sensitivity of yeast to chlorothalonil was improved. The response surface test results were further verified by observing yeast morphology.

According to China's national standard (food pesticide maximum residue limits (GB 2763-2016)), chlorothalonil maximum residue in agricultural products (called simply MRL) in 0.1 $\sim 70 \mathrm{mg} / \mathrm{kg}$. Chlorothalonil has been included in the list of chemical carcinogens in the United States. Compared to the maximum residue limits of our country of chlorothalonil in food, the yeast cells' sensitivity of chlorothalonil under the condition of the optimal cultivation was higher than that, which meets the detection limit of chlorothalonil residue in food. In addition, the optimal yeast cells would be used to detect heavy metals in waste water, evaluate the bioavailability and the biological effect of waste water, and the accuracy and reproducibility were good. Thus, the method of using yeast cells as biosensor to detect the residue of chlorothalonil in food provides a new idea for the detection of heavy metals in the environment.

\section{Acknowledgements}

Authors acknowledge the authorities of Shanghai University of technology for providing the facilities to carry out this work. 


\section{References}

1 Guerreiro A D S, Rola R C, Rovani M T, et al. Antifouling biocides: Impairment of bivalve immune system by chlorothalonil[J]. Aquat Toxicol, 2017,189:194-199.

$2 \mathrm{Wu}$ X, Yin Y, Wang S, et al. Accumulation of chlorothalonil and its metabolite, 4-hydroxychlorothalonil, in soil after repeated applications and its effects on soil microbial activities under greenhouse conditions[J]. Environmental Science and Pollution Research, 2014, 21(5):3452 3459.

3 Arinaitwe K, Kiremire B T, Muir D C G, et al. Legacy and currently used pesticides in the atmospheric environment of Lake Victoria, East Africa[J]. Science of the Total Environment, 2016, 543(PtA):9 18.

4 EPA, 1999. Chlorothalonil〈 http:// archive.epa.gov/pesticides/reregistration/web/pdf/0097fact.pdf $\rangle$. (Accessed on 14 December 2017).

5 FAO/WHO. Pesticide Residues in Food. FAO Plant Production and Protection.1992, 116: 29-31.

6 Wieczerzak M , Namieś Nik J , KudłAk B. Bioassays as one of the Green Chemistry tools for assessing environmental quality: A review[J]. Environment International, 2016, 94:341 361.

7 Hussain M M, Amanchi N R, Solanki V R, et al. Low cost microbioassay test for assessing cytopathological and physiological responses of ciliate model Paramecium caudatum to carbofuran pesticide[J]. Pesticide Biochemistry and Physiology, 2008, 90(1):66-70.

8 Pingli D, Jack C J, Mortensen A N, et al. The impacts of chlorothalonil and diflubenzuron on Apis mellifera L. larvae reared in vitro[J]. Ecotoxicology and Environmental Safety, 2018, 164:283-288.

9 Scariot F J, Luciane J, Delamare A P L, et al. Necrotic cell death induced by dithianon on, Saccharomyces cerevisiae[J]. Pesticide Biochemistry and Physiology, 2018:149:137-142.

10 Liang B, Lu X, Wang G, et al. Functional cell-surface display of acetylcholinesterase for spectrophotometric sensing organophosphate pesticide[J]. Sensors and Actuators B: Chemical, 2018, 279: 483-489.

11 Westlund P, Yargeau V. Investigation of the presence and endocrine activities of pesticides found in waste water effluent using yeast $\sim$ based bioassays[J]. Science of the Total Environment, 2017, 607-608:744.

12 StypułA-TreBas S, Minta M, Radko L, et al. Application of the yeast $\sim$ based reporter gene bioassay for the assessment of estrogenic activity in cow's milk from Poland[J]. Environmental Toxicology and Pharmacology, $2015,40(3): 876-885$.

13 Znag Y, Ren T, He J, et al. Acute heavy metal toxicity test based on bacteriahydrogel[J]. Colloids and Surfaces A,2019, 563:318-323. 
14 Kusumahastutia K.A. D, Sihtmäeb M, Kapitanov Illia V, et al. Toxicity profiling of 24 L phenylalanine derived ionic liquids based on pyridinium, imidazolium and cholinium cations and varying alkyl chains using rapid screening Vibrio fischeri bioassay[J]. Ecotoxicology and Environmental Safety, 2019, 172:556-565.

15 Braconi D, Bernardini G, Santucci A. Saccharomyces cerevisiae as a model in ecotoxicological studies: A post-genomics perspective[J]. Journal of proteomics, 2015, 137:19-34.

16 Hettwer K, JäHne M, Frost K, et al. Validation of, Arxula, Yeast Estrogen Screen assay for detection of estrogenic activity in water samples: Results of an international interlaboratory study[J]. Science of The Total Environment, 2018, 621:612-625.

17 Leskinen P, Hilscherova K, Sidlova T, et al. Detecting AhR ligands in sediments using bioluminescent reporter yeast[J]. Biosensors \& Bioelectronics, 2008, 23(12):1850-1855.

18 Rumlova L, Dolezalova J. A new biological test utilising the yeast Saccharomyces cerevisiae for the rapid detection of toxic substances in water[J]. Environmental Toxicology and Pharmacology, 2012, 33(3):0-464.

19 Scariot Fernando J, Jahn Luciane, Delamare Ana Paula L, et al. Necrotic cell death induced by dithianon on Saccharomyces cerevisiae[J]. Pesticide biochemistry and physiology, 2018,149.

20 Xuejiang W, Mian L, Xin W, Zhen W, et al. P -benzoquinone-mediated amperometric biosensor developed with Psychrobacter sp. for toxicity testing of heavy metals[J]. Biosensors and Bioelectronics, 2013, 41. online alert of $\mathrm{Cu}(\mathrm{II})$ shock.[J]. Biosensors \& bioelectronics, 2019, 142.

22 Yachen D. Analysis of programmed cell death induced by acetic in Saccharomyces cerevisiae based on omics technology [D]. Zhejiang University, 2015.

23 Zhisong C, Luan X, Huichao J, et al. Application of a bacterial whole cell biosensor for the rapid detection of 
bioRxiv preprint doi: https://doi.org/10.1101/2020.01.07.898106; this version posted January 9,2020 . The copyright holder for this preprint (which was not certified by peer review) is the author/funder, who has granted bioRxiv a license to display the preprint in perpetuity. It is made available under aCC-BY-NC 4.0 International license. 